\title{
The Social Profile of Students in Basic General Education in Ecuador: A Data Analysis
}

\author{
Olga Elizabeth Minchala Buri ${ }^{1} \&$ Efstathios Stefos ${ }^{1}$ \\ ${ }^{1}$ National University of Education (UNAE), Azogues, Ecuador \\ Correspondence: Efstathios Stefos, National University of Education (UNAE), Azogues, Cañar, Parroquia Javier \\ Loyola (sector Chuquipata), Ecuador. Tel: 593-7-370-1200. E-mail: estefos@aegean.gr
}

Received: January 17, 2016

Accepted: February 26, 2017 Online Published: May 29, 2017

doi:10.5539/ies.v10n6p51

URL: https://doi.org/10.5539/ies.v10n6p51

\begin{abstract}
The objective of this study is to examine the social profile of students who are enrolled in Basic General Education in Ecuador. Both a descriptive and multidimensional statistical analysis was carried out based on the data provided by the National Survey of Employment, Unemployment and Underemployment in 2015. The descriptive analysis shows the frequency and percentages of variables used in the investigation, and the multidimensional statistical analysis demonstrates the principal and more important criteria of differentiation and classification among the clusters of students who were investigated. These methods involve factorial analysis of multiple correspondences which demonstrate criteria of differentiation and a hierarchical cluster analysis to define clusters of students according to their common traits.
\end{abstract}

Keywords: students of basic general education, Ecuador, social profile, data analysis

\section{Introduction}

During the last fifteen years, Ecuador has established national and international agreements regarding education. The main objective of these agreements has been to guarantee the quality of national education with equity, intercultural, and inclusive vision in order to strengthen citizen training and unity among the Ecuadorian society.

The Ecuadorian educational system is an integrated, decentralized and flexible system, which meets the needs of individual and social learning, contributes to cultural identity, and promotes unity in diversity. As well as it aims to consolidate a society with intercultural awareness, strengthen the multi-cultural and multiethnic country with a universal vision, reflexive, critical, participatory, supportive and democratic. Besides that, the Ecuadorian educational system encourages the use of developing knowledge, skills and values to ensure competitiveness, productivity and technical and scientific development, and thus to make a better living for Ecuadorians, and achieve sustainable development in the country.

Through its educational institutions, the Ecuadorian educational system offers a higher learning education which allows the fulfillment of this vision, and based on the principles such as: quality, equity, inclusion, relevance, participation, accountability, diversity, flexibility and efficiency, the different components of the national educational system pursues the commitment and participation in the construction of knowledge of society (Castellano et al., 2017).

Therefore, the purpose of the Ecuadorian educational institutions is to shape citizens, men and women, who will be creative, critical, solidarity and deeply committed to social change. Individuals who feels proud of their national identity, who contributes to the construction of the multicultural, and multi-ethnic state always preserving their territorial sovereignty and their natural resources. Likewise, each school has the commitment to guarantee the development of ancestral languages, develop students' civic and moral values, and have capacity for self-management and generate productive work. Educators shall participate actively in the development of the country which is required for its integration into the international community; and shall contribute to the consolidation of a non-dependent democracy, in which peace, gender, equality, and social justice are the main principles to be respected and valued in all human beings.

This is why; this study's aim is to investigate the social profile of Basic General Education students in Ecuador. Basic General Education in Ecuador encompasses ten levels of study, first grade through tenth grade. Students who complete these levels are able to continue their studies towards a Unified General Baccalaureate. 
Basic General Education levels enable students to develop communication skills, interpret and solve problems, and develop understanding of natural and social life. Those students who complete the Basic General Education studies develop competency in demonstrating logical, critical and creative thinking skills, as well as improve their problem solving skills in everyday situations. At the same time, students of Basic Education apply technologies to communicate, and find out solution to practical problems by doing research, and training on academic activities.

Basic General Education Curriculum is organized by areas, educational levels and sub-levels; it develops a selection of basic contents (skills with performance criteria) appropriate to the requirements of society and school environment. Therefore, in order for the Basic General Education students, to move towards the exit profile, they must develop knowledge in the following areas of learning: Language and Literature, Mathematics, Natural Sciences, Social Sciences, Foreign Language, Physical Education, Cultural and Art Education. These are the areas studied throughout Basic General Education until the last year of the Unified General Baccalaureate, constituting a longitudinal division of the area throughout the mandatory areas of study (Ministerio de Educación de Ecuador, 2016).

The data compiled in this paper can be compared with data from other countries regarding their education system and students' profile and level of education for the purpose of promoting better education based on the interests and needs of each country (OECD, 2016).

\section{Method}

The study uses as reference statistical information from the 2015 National Survey of Employment, Unemployment and Underemployment (INEC, 2015). Given the objective of the present study, a descriptive and a multidimensional statistical analysis were done, with the former showing the frequency and percentages of the variables under investigation (Athanasiadis, 1995).

Multidimensional statistical analysis, on the other hand, is used to illustrate the principal and most important criteria of differentiation and classification of students into clusters. The methods of the Multidimensional statistical analysis that we used are the Multiple Correspondence Analysis, which defines the differentiation criteria and the Hierarchical Clustering that presents the groups of the persons according to their common characteristics. In other words, the factorial axes are the criteria of differentiation which elucidate the opposing points in the answer of the subjects, while the hierarchical analysis shows the clusters of students according to their replies and common traits.

SPAD v 4.5 software offered by the Faculty of Humanities of the University of the Aegean was used to analyze the data.

\section{Descriptive Analysis}

$63.39 \%$ of students are from urban areas and $36.60 \%$ are from rural areas (Table 1).

Table 1. Area of residence

\begin{tabular}{ccc}
\hline & $\mathrm{n}$ & $\%$ \\
\hline Urban & 2168529 & $63.39 \%$ \\
Rural & 1252204 & $36.60 \%$ \\
Total & 3420734 & $100.00 \%$ \\
\hline
\end{tabular}

$50.96 \%$ of students are men and $49.04 \%$ are women (Table 2 ).

Table 2. Sex

\begin{tabular}{lcc}
\hline & $\mathrm{n}$ & $\%$ \\
\hline Men & 1743190 & $50.96 \%$ \\
Women & 1677544 & $49.04 \%$ \\
Total & 3420734 & $100.00 \%$ \\
\hline
\end{tabular}

9.67\% of students are 5 years old, $9.27 \%$ are 6 years old, $9.96 \%$ are 7 years old, $9.75 \%$ are 8 years old, $9.88 \%$ are 9 years old, $9.12 \%$ are 10 years old, $9.48 \%$ are 11 years old, $8.97 \%$ are 12 years old, $9.32 \%$ are 13 years old, $8.80 \%$ are 14 years old, and $5.78 \%$ of students are more than 14 years old (Table 3 ). 
Table 3. Age

\begin{tabular}{lcc}
\hline & $\mathrm{n}$ & $\%$ \\
\hline 5 & 330756 & $9.67 \%$ \\
6 & 317200 & $9.27 \%$ \\
7 & 340601 & $9.96 \%$ \\
8 & 333404 & $9.75 \%$ \\
9 & 338031 & $9.88 \%$ \\
10 & 311889 & $9.12 \%$ \\
11 & 324319 & $9.48 \%$ \\
12 & 306958 & $8.97 \%$ \\
13 & 318857 & $9.32 \%$ \\
14 & 300943 & $8.80 \%$ \\
More than 14 years & 197777 & $5.78 \%$ \\
Total & 3420734 & $100.00 \%$ \\
\hline
\end{tabular}

$99.82 \%$ of students attend classes and $0.18 \%$ do not attend classes (Table 4 ).

Table 4. Attend class

\begin{tabular}{lcc}
\hline & $\mathrm{n}$ & $\%$ \\
\hline Yes & 3414554 & $99.82 \%$ \\
No & 6180 & $0.18 \%$ \\
Total & 3420734 & $100.00 \%$ \\
\hline
\end{tabular}

$82.44 \%$ of students attend classes in the morning, $15.91 \%$ in the afternoon, $0.53 \%$ in the evening, $0.01 \%$ attend all-day classes, $0.37 \%$ attend classes in two periods, $0.57 \%$ at distance, and $0.18 \%$ do not attend classes (Table 5).

Table 5. Time of attendance

\begin{tabular}{lcc}
\hline & $\mathrm{n}$ & $\%$ \\
\hline Morning & 2819911 & $82.44 \%$ \\
Afternoon & 544104 & $15.91 \%$ \\
Evening & 18047 & $0.53 \%$ \\
All day & 376 & $0.01 \%$ \\
Two periods & 12686 & $0.37 \%$ \\
At distance & 19429 & $0.57 \%$ \\
NA & 6180 & $0.18 \%$ \\
Total & 3420734 & $100.00 \%$ \\
\hline
\end{tabular}

$0.02 \%$ of students do not attend classes due to lack of economic resources, $0.01 \%$ due to school failure, $0.01 \%$ due to illness or disability, $0.001 \%$ due to lack of family support, $0.001 \%$ due to shortage of educational institutions, $0.01 \%$ are not interested, $0.08 \%$ due to lack of positions, $0.04 \%$ other, and $99.82 \%$ do not attend classes (Table 6).

Table 6. Reason for not attending

\begin{tabular}{lcc}
\hline & $\mathrm{n}$ & $\%$ \\
\hline Lack of economic resources & 629 & $0.02 \%$ \\
School failure & 482 & $0.01 \%$ \\
Illness or disability & 432 & $0.01 \%$ \\
Lack of family support & 28 & $0.001 \%$ \\
Shortage of educational institutions & 43 & $0.001 \%$ \\
Not interested & 328 & $0.01 \%$ \\
\hline
\end{tabular}




\begin{tabular}{lcc}
\hline Lack of positions & 2819 & $0.08 \%$ \\
Other & 1419 & $0.04 \%$ \\
NA & 3414554 & $99.82 \%$ \\
Total & 3420734 & $100.00 \%$ \\
\hline
\end{tabular}

$0.17 \%$ of the students' parents speak only indigenous language, $9.11 \%$ indigenous and Spanish language, $89.74 \%$ only Spanish, $0.97 \%$ Spanish and foreign language, $0.002 \%$ indigenous language and foreign language, $0.001 \%$ foreign language and $0.01 \%$ do not speak (Table 7).

Table 7. Parents' language

\begin{tabular}{lcc}
\hline & $\mathrm{n}$ & $\%$ \\
\hline Only Indigenous language & 5798 & $0.17 \%$ \\
Indigenous and Spanish language & 311710 & $9.11 \%$ \\
Only Spanish & 3069684 & $89.74 \%$ \\
Spanish and foreign language & 33047 & $0.97 \%$ \\
Indigenous language and foreign language & 76 & $0.002 \%$ \\
Foreign language & 21 & $0.001 \%$ \\
Do not speak & 398 & $0.01 \%$ \\
Total & 3420734 & $100.00 \%$ \\
\hline
\end{tabular}

$0.15 \%$ of students speak only indigenous language, $6.16 \%$ speak indigenous and Spanish language, $93.00 \%$ only Spanish, $0.53 \%$ Spanish and foreign language, $0.01 \%$ indigenous and foreign language, $0.13 \%$ foreign language, and $0.03 \%$ do not speak (Table 8 ).

Table 8. Students' language

\begin{tabular}{lcc}
\hline & $\mathrm{n}$ & $\%$ \\
\hline Only indigenous language & 5294 & $0.15 \%$ \\
Indigenous and Spanish language & 210591 & $6.16 \%$ \\
Only Spanish & 3181123 & $93.00 \%$ \\
Spanish and foreign language & 18005 & $0.53 \%$ \\
Indigenous language and foreign language & 229 & $0.01 \%$ \\
Foreign language & 4302 & $0.13 \%$ \\
Do not speak & 1190 & $0.03 \%$ \\
Total & 3420734 & $100.00 \%$ \\
\hline
\end{tabular}

$10.60 \%$ of students consider themselves indigenous, $1.34 \%$ Afro-Ecuadorian, $2.09 \%$ black, $1.40 \%$ mulatto, $4.72 \%$ montubio, $78.41 \%$ mestizo, and $1.42 \%$ white (Table 9 ).

Table 9. Ethnic self-identification

\begin{tabular}{lcc}
\hline & $\mathrm{n}$ & $\%$ \\
\hline Indigenous & 362467 & $10.60 \%$ \\
Afro-Ecuadorian & 45882 & $1.34 \%$ \\
Black & 71648 & $2.09 \%$ \\
Mulatto & 47827 & $1.40 \%$ \\
Montubio & 161316 & $4.72 \%$ \\
Mestizo & 2682214 & $78.41 \%$ \\
White & 48730 & $1.42 \%$ \\
Other & 650 & $0.02 \%$ \\
Total & 3420734 & $100.00 \%$ \\
\hline
\end{tabular}

$80.50 \%$ of students were born in the same city they are living now, $18.14 \%$ were born elsewhere in the country, 
and $1.36 \%$ was born in another country (Table 10$)$.

Table 10. Place of birth

\begin{tabular}{lcc}
\hline & $\mathrm{n}$ & $\%$ \\
\hline In this city & 2753721 & $80.50 \%$ \\
Elsewhere in the country & 620611 & $18.14 \%$ \\
In other country & 46402 & $1.36 \%$ \\
Total & 3420734 & $100.00 \%$ \\
\hline
\end{tabular}

$8.27 \%$ of students use cellphones, and $90.96 \%$ do not use cellphones (Table 11).

Table 11. Use of cellphones

\begin{tabular}{lcc}
\hline & $\mathrm{n}$ & $\%$ \\
\hline Yes & 283052 & $8.27 \%$ \\
No & 3111521 & $90.96 \%$ \\
NA & 26161 & $0.76 \%$ \\
Total & 3420734 & $100.00 \%$ \\
\hline
\end{tabular}

Only $3.71 \%$ of students use smartphones (Table 12 ).

Table 12. Use of smartphone

\begin{tabular}{lcc}
\hline & $\mathrm{n}$ & $\%$ \\
\hline Yes & 126996 & $3.71 \%$ \\
No & 156055 & $4.56 \%$ \\
NA & 3137682 & $91.73 \%$ \\
Total & 3420734 & $100.00 \%$ \\
\hline
\end{tabular}

$58.51 \%$ of students have used computer during the last 12 months, and $40.72 \%$ have not used computer (Table $13)$.

Table 13. Use of computer during the last 12 months

\begin{tabular}{lcc}
\hline & $\mathrm{n}$ & $\%$ \\
\hline Yes & 2001564 & $58.51 \%$ \\
No & 1393009 & $40.72 \%$ \\
NA & 26161 & $0.76 \%$ \\
Total & 3420734 & $100.00 \%$ \\
\hline
\end{tabular}

$54.95 \%$ of students used internet during the last 12 months, and $44.29 \%$ did not use internet (Table 14).

Table 14. Use of internet during the last 12 months

\begin{tabular}{lcc}
\hline & $\mathrm{n}$ & $\%$ \\
\hline Yes & 1879639 & $54.95 \%$ \\
No & 1514934 & $44.29 \%$ \\
NA & 26161 & $0.76 \%$ \\
Total & 3420734 & $100.00 \%$ \\
\hline
\end{tabular}

$42.70 \%$ of students are from the mountain region, $50.50 \%$ are from the coastal region, $6.63 \%$ are from the Amazon region, and $0.16 \%$ is from the insular region (Table 15 ). 
Table 15. Natural region

\begin{tabular}{lcc}
\hline & $\mathrm{n}$ & $\%$ \\
\hline Mountain region & 1460789 & $42.70 \%$ \\
Coastal region & 1727419 & $50.50 \%$ \\
Amazon region & 226888 & $6.63 \%$ \\
Insular region & 5638 & $0.16 \%$ \\
Total & 3420734 & $100.00 \%$ \\
\hline
\end{tabular}

$32.74 \%$ of students suffer income poverty, and $66.31 \%$ do not suffer income poverty (Table 16 ).

Table 16. Income poverty

\begin{tabular}{lcc}
\hline & $\mathrm{n}$ & $\%$ \\
\hline Not poor & 2268391 & $66.31 \%$ \\
Poor & 1120067 & $32.74 \%$ \\
NA & 32275 & $0.94 \%$ \\
Total & 3420734 & $100.00 \%$ \\
\hline
\end{tabular}

$12.56 \%$ of students are indigent, and $86.50 \%$ are not indigent (Table 17 ).

Table 17. Extreme income poverty

\begin{tabular}{lcc}
\hline & $\mathrm{n}$ & $\%$ \\
\hline Not indigent & 2958853 & $86.50 \%$ \\
Indigent & 429606 & $12.56 \%$ \\
NA & 32275 & $0.94 \%$ \\
Total & 3420734 & $100.00 \%$ \\
\hline
\end{tabular}

\section{Factorial Analysis of Multiple Correspondences}

The method of factorial analysis of multiple correspondences was utilized with the objective of revealing how the subjects of the survey differ according to their answers (Stefos \& Koulianidi, 2016). The criteria which differentiate the surveyed students are:

The first criterion of differentiation (percentage of inertia 13.48\%)

The first differentiation criterion is consisted on one hand of students who consider themselves mestizo, speak only Spanish, live in urban areas of the coastal region, are not indigent, do not suffer from income poverty, and they did not use neither computer or internet during the last twelve months. On the other hand, there are students who consider themselves indigenous, they speak indigenous and Spanish language, live in rural areas of Amazon region, and suffer from poverty.

The second criterion of the differentiation (percentage of inertia 9.16\%)

The second differentiation criterion is consisted on one hand of students who use smartphones, have used computer and internet during the last twelve months, are indigenous from the Amazon region, and speak indigenous language and Spanish. On the other hand, there are students who do not have smartphones, and have not used computer or internet during the last twelve months, their parents speak only Spanish and they are from the Coast region.

The third criterion of differentiation (percentage of inertia 6.18\%)

The third differentiation criterion is consisted on one hand of students who do not own an active cellphone, have used computer and internet during the last twelve months, are 10 or 11 years old, and are from the mountain region. On the other hand, there are students with active smartphones, who have not used computer or internet during the last twelve months, are between 5 to 14 years of age, and are from the coastal region.

\section{Hierarchical Analysis}

The hierarchical analysis consists of eight clusters of students (Valdivieso et al., 2017). 


\section{First cluster $(25.84 \%$ of the sample)}

The first cluster consists of students who consider themselves mestizo, used computer and internet during the last twelve months, and are not poor. These students speak only Spanish and attend school in the mornings.

\section{Second cluster (11.20\% of the sample)}

The second cluster consists of students who attend school in the afternoons, have used computer and internet during the last twelve months, are from the coastal region, live in urban areas, and speak only Spanish.

\section{Third cluster ( $7.66 \%$ of the sample)}

The third cluster consists of students who consider themselves mestizo, speak only Spanish, attend classes in the mornings, do not own an active cellphone and have not used a computer or internet during the last twelve months.

\section{Fourth cluster (9.95\% of the sample)}

The fourth cluster consists of students who are indigents, live in rural areas, and speak only Spanish. These students have not used the internet during the last twelve months, do not have an active cellphone, and attend school in the mornings.

\section{Fifth cluster (14.28\% of the sample)}

The fifth cluster consists of students who have not used computers and internet during the last twelve months, speak only Spanish, are from the coastal region, do not have an active cellphone, and are not indigents.

\section{Sixth cluster $(8.57 \%$ of the sample)}

The sixth cluster consists of students who are 5 years old, have not used a computer or internet during the last twelve months, speak Spanish, consider themselves mestizo, are not indigent, and do not have an active cellphone.

\section{Seventh cluster ( $8.23 \%$ of the sample)}

The seventh cluster consists of students who have an active smartphone, have used computers and internet during the last twelve months, most of them are 14 years old, are not poor and live in urban areas.

\section{Eighth cluster (14.26\% of the sample)}

The eighth cluster consists of students who live in rural areas, have not used computers and internet during the last twelve months, do not have an active cellphone, are poor and the majority of them consider themselves indigenous.

The differences between these clusters can be seen in Figure 1 where the Correspondence Analysis graph (factorial levels 1x2) presents the centroids of the eight groups in the two axes. Additionally, it defines the differences and similarities between the students of these eight groups (Stefos \& Papapostolou, 2013).

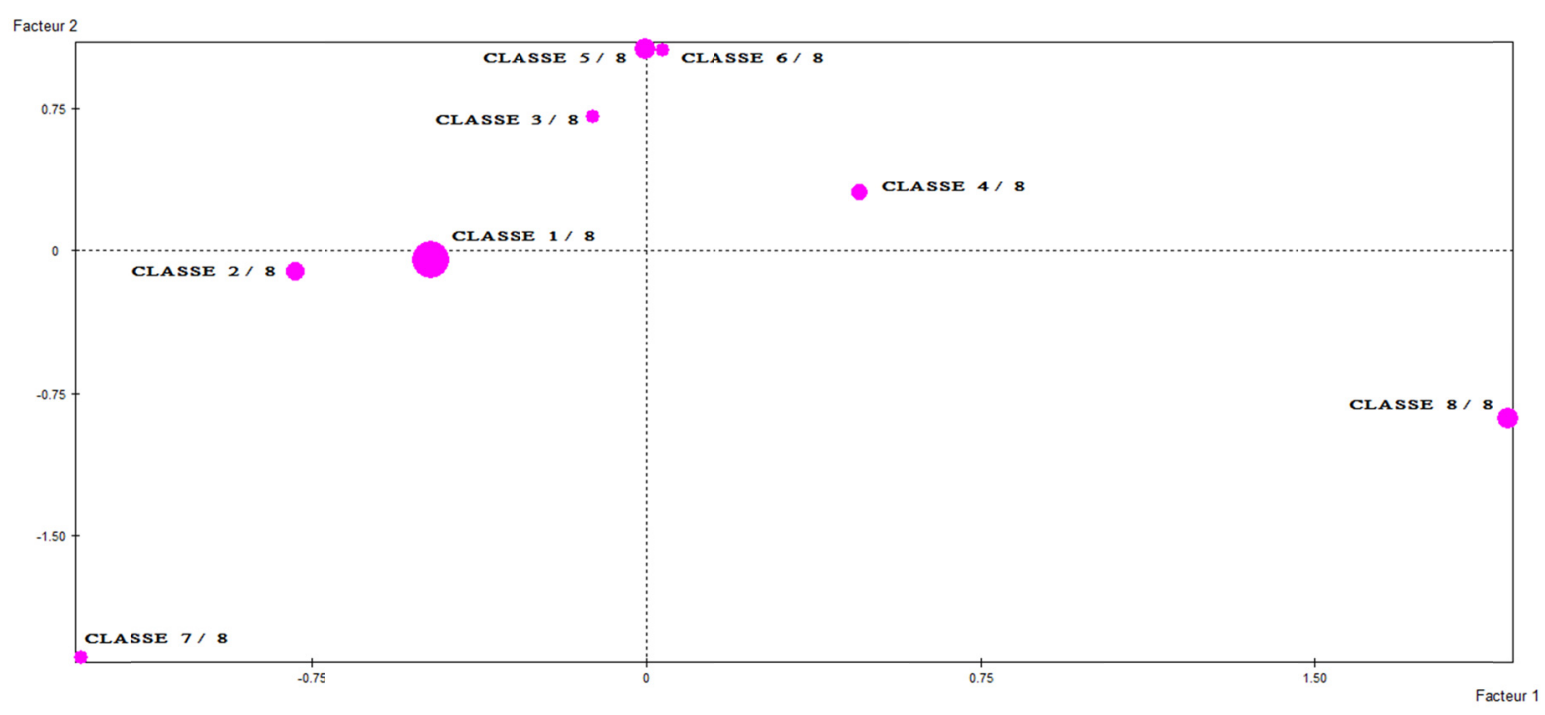

Figure 1. Correspondence analysis 


\section{Conclusion}

The aim of the present study was to investigate the social profile of the students of the Basic General Education of Ecuador. We used the National Survey of Employment, Unemployment and Underemployment of 2015 and investigated the variables: area of residence, sex, age, attend class, time of attendance, reason for not attending, parents' language, students' language, ethnic self-identification, place of birth, use of cellphones, use of smartphone, use of computer, use of internet, natural region, income poverty, and extreme income poverty (Kampouropoulou et al., 2015).

The descriptive analysis showed the frequency and percentages of the variables used in the investigation, while the multidimensional statistical analysis showed the principal and most important criteria of differentiation and classification among the clusters of students under investigation (Stefos, 2015).

The results of the descriptive analysis are confirmed by the multiple correspondence analysis and the hierarchical classification (Morineau, 1984). The analysis of the data showed that $78.41 \%$ of students of Basic General Education in Ecuador consider themselves mestizo and 10.60\% indigenous; $93.00 \%$ speak only Spanish and $6.16 \%$ speak indigenous and Spanish language; $82.44 \%$ attend classes in the morning and $15.91 \%$ in the afternoon; only $0.18 \%$ of the students do not attend classes; $8.27 \%$ of students use cellphones, $3.71 \%$ smartphones, $58.51 \%$ computers and $54.95 \%$ internet; $32.74 \%$ of students suffer income poverty and $12.56 \%$ are indigent (Stefos et al., 2011).

\section{Acknowledgments}

We would like to express our deepest gratitude to the Faculty of Humanities of the University of the Aegean for donating the statistical software SPAD v.4.5 used in this study.

\section{References}

Athanasiadis, I. (1995). Correspondence Analysis and Hierarchical Classification (pp. 51-56). Athens: New Technologies Editions.

Benzécri, P. (1992). Correspondence Analysis Handbook. New York: Dekker.

Castellano, J. M., Stefos, E., \& Williams-Goodrich, L. G. (2017). The Educational and Social Profile of the Indigenous People of Ecuador: A Multidimensional Analysis. Review of European Studies, 9(1), 137-147. https://doi.org/10.5539/res.v9n1p137

Instituto Nacional de Estadística y Censos - INEC. (2015). Encuesta Nacional de Empleo, Desempleo y Subempleo - ENEMDU, 2015. Quito, Ecuador.

Kampouropoulou, M., Fokiali, P., Efstathiou, I., Koutris, T., \& Stefos, E. (2015). Students' Views on the Use of a Virtual Educational Museum, Review of European Studies, 7(11), 1-6. https://doi.org/10.5539/res.v7n11p1

Ministerio de Educación. (2016). Currículo de los niveles de educación. Quito, Ecuador.

Morineau, A. (1984). Note sur la Caracterisation Statistique d'une Classe et les Valeurs-tests. Bulletin Technique du Centre de Statistique et d'Informatique Appliquées, 2(1-2), 20-27.

OECD. (2016). Education at a glance 2016. Organisation for Economic Cooperation and Development. https://doi.org/10.1787/eag-2016-en

Olivier, M. (2008). The analysis of quantitative data, Transl. Athanasiadis, I. (pp.86-88). Athens: Topos.

Papapostolou, I., \& Stefos, E. (2013). Qualitative analysis on pedagogical research. Methodological approaches. In I. Papapostolou (Ed.), Educational activities. Teaching Interventions in Secondary Education (pp. 244-251). Rhodes: Evdimos Editions.

Papapostolou, I., Papapostoulou, K., \& Stefos, E. (2013). Educational Research. From Qualitative to Quantitative analysis (p. 178). Rhodes: Evdimos Editions.

Sarmiento-Sarmiento, N. M., Paredes-Proaño, A. M., \& Stefos, E. (2016). Deaths by Suicide in Ecuador: A Quantitative Data Analysis. Review of European Studies, 8(1), 145-156. https://doi.org/10.5539/res.v8n1p145

Stefos, E. (2015). Causes of Death of Indigenous Ecuadorians. International Journal of Clinical Medicine Research, 2(6), 65-70.

Stefos, E., \& Koulianidi, G. (2016). Nutrition Data Analysis Using R: Applications in Higher Education. Health Sciences Research. 3(1), 10-16. 
Stefos, E., \& Papapostolou, I. (2013). Research Methodology. Processes and suggestions (p. 406). Rhodes: Evdimos Editions.

Stefos, E., Athanasiadis I., Gialamas, B., \& Tsolakidis, C. (2011). The Use of New Technologies and the Project Method in Teaching Statistics: A Case Study in Higher Education. HMS i JME, 3, 84-100.

Valdivieso, G., Stefos, E., \& Lalama, R. (2017). The Ecuadorian Amazon: A Data Analysis of Social and Educational Characteristics of the Population. Review of European Studies, 9(1), 120-129. https://doi.org/10.5539/res.v9n1p120

\section{Copyrights}

Copyright for this article is retained by the author(s), with first publication rights granted to the journal.

This is an open-access article distributed under the terms and conditions of the Creative Commons Attribution license (http://creativecommons.org/licenses/by/4.0/). 